Available online at: www.cahiersagricultures.fr

\title{
Oil palm cultivation in the Americas: review of the social, economic and environmental conditions of its expansion
}

\author{
Colombine Lesage ${ }^{1,2,3}$, Jaime Cifuentes-Espinosa ${ }^{3,4}$ and Laurène Feintrenie ${ }^{3,5,6,7, *}$ \\ ${ }^{1}$ ENSAIA, Université de Lorraine, Nancy, France \\ 2 HEC Montréal, Montréal, Canada \\ ${ }^{3}$ CIRAD, UPR Forêts et Sociétés, F-34398 Montpellier, France \\ ${ }^{4}$ El Colegio de la Frontera Sur, Campeche, Mexico \\ 5 CATIE, División de Investigación para el Desarrollo Verde e Inclusivo, Turrialba, Costa-Rica \\ ${ }^{6}$ ICRAF, Latin America Office, Lima, Perú \\ ${ }^{7}$ Forêts et Sociétés, Univ Montpellier, Montpellier, France
}

\begin{abstract}
In the Americas, the palm oil sector has been gaining importance in the last 20 years. Although in 2018 the region only accounted for $7.1 \%$ of global palm oil production, it is one of the largest suitable areas for oil palm cultivation. We conducted a literature review on how the sector developed and how its development influenced private and public actors in their choice among three categories of arrangements between oil palm growers and palm oil extraction units. We grouped cases reported in the literature in three categories: corporate models, contract farming, and growers' organizations. The two latter categories emerged in response to the call for better inclusion of growers in the value chain, for local development, and for sustainable production; they now represent almost $30 \%$ of production in the region. All the parties involved are pushing for more sustainable production. National governments intend to regulate production, and private companies are engaging in certification and fair partnerships with producers of fruit bunches. However, there are still many negative impacts on the environment, on local populations, and on biodiversity. Thus, although the Americas appear to be on the way to being leaders of sustainability in the palm oil sector, challenges remain.
\end{abstract}

Keywords: environmental degradation / extensive farming / resource depletion / socioeconomic development / sustainable agriculture

Résumé - La culture du palmier à huile en Amérique: une revue des conditions sociales, économiques et environnementales de son expansion. En Amérique, le secteur de l'huile de palme a pris de l'importance depuis 20 ans. Bien que la région ne représente, en 2018, que 7,1\% de la production mondiale, elle possède l'une des plus vastes superficies propices à la culture du palmier à huile. Cette étude repose sur une revue de la littérature centrée sur l'évolution historique du secteur et la façon dont cette évolution a influencé les acteurs privés et publics dans leur choix entre trois catégories d'arrangements entre les planteurs et les unités d'extraction d'huile. Nous avons groupé les cas présentés dans la littérature en 3 catégories: le modèle entrepreneurial, l'agriculture contractuelle et les organisations de planteursextracteurs. Ces deux dernières catégories sont apparues pour promouvoir une meilleure inclusion des producteurs dans la filière, un développement local et une durabilité de la production. Elles représentent désormais près de $30 \%$ de la production régionale. Toutes les parties prenantes poussent à une production plus durable. Les États tentent de réguler la production et les entreprises privées s'engagent dans la certification et dans des partenariats équitables avec les producteurs de régimes. Cependant, les impacts négatifs sur l'environnement, sur les populations locales et sur la biodiversité restent nombreux. Ainsi, bien que l'Amérique semble en bonne voie pour développer le secteur de l'huile de palme de manière durable et équitable, les défis demeurent importants.

Mots clés : dégradation de l'environnement / agriculture extensive / épuisement des ressources / développement socioéconomique / agriculture durable

*Corresponding author: laurene.feintrenie@cirad.fr 


\section{Introduction}

Since 2000, oil palm cultivation has been expanding considerably worldwide. In 2019, the area under oil palm (28 Mha) was mainly located in South East Asia (74\%), followed by Africa (20\%), America (5\%) and Oceania (1\%); total oil palm fruit production reached $410 \mathrm{Mt}$ in 2019 , for a global palm oil production of $71 \mathrm{Mt}$. South East Asia accounted for almost $88 \%$ of world production, while the Americas, Africa, and Oceania accounted for respectively, $6 \%$, $5 \%$ and $1 \%$ (FAO, 2020). This expansion is due to increased demand for edible vegetable oil - predicted to reach $240 \mathrm{Mt}$ by 2050 - and policies to promote supply (Byerlee et al., 2017).

Following its rapid expansion in South East Asia, oil palm cultivation raised many environmental and social controversies (Meijaard and Sheil, 2019). The economic benefits are frequently mentioned, but may not be equitably distributed (Santika et al., 2019). Negative impacts on biodiversity and ecosystem services (deforestation, biodiversity loss, pollution, water quality), as well as social aspects (land grabbing, unfair partnerships between industries and smallholders, indebtedness, human rights abuses) are often quoted (Meijaard et al., 2018; Qaim et al., 2020). In response to the growing tensions regarding oil palm expansion, some of the main palm oil groups collaborated with non-governmental organizations (NGOs) to create the Roundtable on Sustainable Palm Oil (RSPO) in 2004. In the meantime, nearly all large companies have announced No Deforestation, no Peat, no Exploitation (NDPE) commitments (Pacheco et al., 2017).

Since 2001, the sector has undergone 7\% annual growth in the Americas (Furumo and Aide 2017). Pirker et al. (2016) calculated that 1367 Mha are suitable for oil palm worldwide, of which $725 \mathrm{Mha}$ are in the Americas. These authors estimated that most of this area is occupied by land uses of high conservation value including protected areas, forests with high carbon stocks and rich biodiversity, which leaves a worldwide potential of about $17 \%$ of the initial value. They concluded that $83.68 \mathrm{Mha}$ are available for oil palm expansion in the Americas (Pirker et al., 2016).

Based on this observation, we conducted a literature review to understand the past and current dynamics of the palm oil sector in the Americas and to identify future prospects in the specific context of the region. The paper is organized as follows: Section 2 presents the methodology we used for our literature review; Section 3 presents the historical development of the sector, explains its advent and its organization; and Section 4 reports the impacts of its expansion as listed in the literature. Section 5 discusses possible pathways for sustainable oil palm development in the Americas. Sustainable oil palm production is defined as having a positive or neutral impact on biodiversity and ecosystem services, preserving high conservation value areas, being inclusive and fair to all actors of the value chain and respecting minority rights over land and ecosystems, using land that is suitable for oil palm cultivation and is available (i.e., is not legally protected for conservation, or targeted for other uses, and is not required for food crops), and finally is profitable for the producers (be they individuals or enterprises). We assess these pathways based on current trends and situations presented hereafter.

\section{Material and methods}

Based on an extensive literature research, this paper describes current insights into the diverse components of the development of palm oil production in the Americas: public policies, modes of production, social and environmental impacts. The points raised in the analysis are illustrated by references to the most relevant documents. Our systematic literature review covered grey literature, peer-reviewed articles, scientific reports, books and media in English, French, Portuguese and Spanish.

The first searches were made on general scientific online databases using the search terms: "oil palm" or "palm oil", associated with "Latin America", "South America", "Caribbean" or "Central America" and their translations. Oil palm literature has grown steadily since the 1960 s, with an acceleration since 2000. The number of publications per year on the Americas has also been increasing since 2008. In August 2017, nearly 1500 scientific publications on oil palm production in the Americas were listed by $\mathrm{CAB}$ Direct. All producing countries are not the subjects of the same number of studies. In the CAB Direct database, in 2017, Brazil accounted almost 50\% of the publications (942 articles), followed by Colombia $(23 \%)$, Costa Rica (7\%), Mexico (6\%), Ecuador (5\%) and Peru (5\%) (CAB Direct, 2017).

We conducted a country scale review to study each selected topic in more depth. To do so, we repeated the previous searches but replaced the term "Latin America" by the producing countries, as listed by USDA (2017): Brazil, Colombia, Costa-Rica, Dominican Republic, Ecuador, El Salvador, Guatemala, Honduras, Mexico, Nicaragua, Panama, Paraguay, Peru, Suriname, and Venezuela. We completed the review of the scientific literature with specific searches of general online databases, websites of domestic and international institutions, ministries, associations, NGOs, national and international research centers, universities, private companies, and other media sources.

To address our research question, we focused on the history of the sector and its development, organization, current production, uses and impacts, and the public policies that have accompanied its development. We considered all publication dates from all geographic origins, and of all types. We crossreferenced searches and obtained a diversified database of 304 sources. Relevant recent references were added following useful suggestions by the reviewers, increasing the number of references to 325 . First, country specific data extracted from these sources were gathered in a portfolio of 15 country records. Then, a comparative analysis was conducted to discover commonalities and specificities between producer countries.

We classified references in 11 categories: peer-reviewed articles, domestic and international research institute reports, other scientific publications (theses, books, and conference proceedings), media sources, NGOs, private company website, union or cooperative websites, government publications, national and international statistics, institutional reports, RSPO documents, domestic or international juridical acts. Figure 1 shows the range of supports studied and their distribution between the countries. 


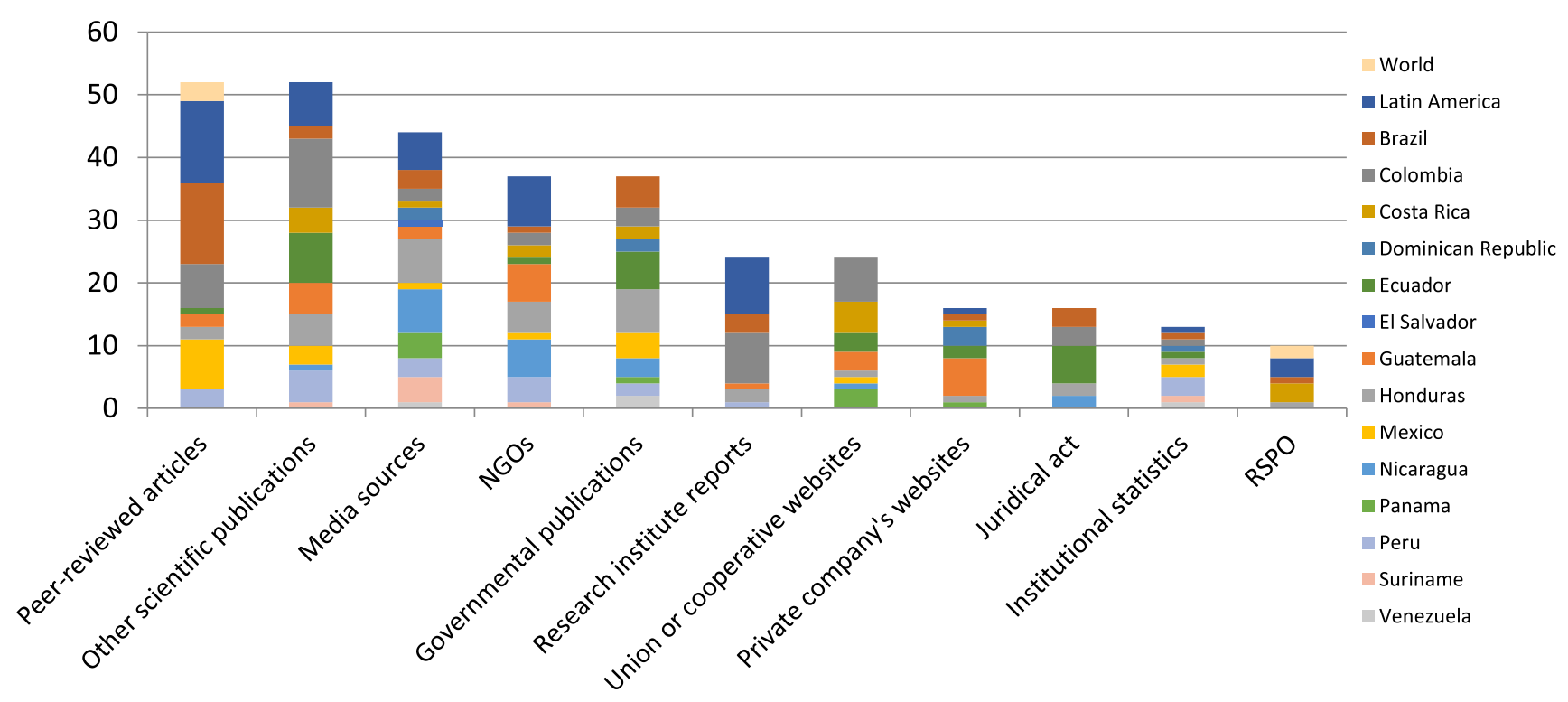

Fig. 1. Distribution of the references per country studied and per type of support. Source: The authors.

Fig. 1. Répartition des supports bibliographiques en fonction du pays étudié et du type de support.

\section{Oil palm history and present dynamics}

\subsection{Historical background of the sector}

The so-called African palm, Elaeis guineensis Jacq., arrived in the Americas, specifically in Brazil, with the African slave trade in the 17th century (Watkins, 2018). It was cultivated only by their descendants until the first half of the 20th century, when the United Fruit Company (UFCo), a North American company that produced and exported bananas, established oil palm production sites in Central America (Les Echos, 2009). Oil palm cultivation was launched as an alternative crop to respond to diseases affecting banana trees and spreading throughout the UFCo plantations during the 1930s.

Between 1936 and 1938, UFCo established the first oil palm plantation in Honduras, followed in 1937, by a plantation in Guatemala (Washburn, 1987). Almost simultaneously, pilot projects were started in Costa Rica (Clare, 2005). UFCo then encouraged the expansion of oil palm in its other divisions to replace banana plantations. Oil palm plantations consequently developed in Costa Rica (1943) (Clare, 2005), Colombia (1945) (Washburn, 1987), Nicaragua (between 1945 and 1950) (IICA, 2006) and Ecuador (1952) (Carrión and Cuvi, 1985). In the late 1950s, the company had over 7000 ha under oil palm, most of which were subsequently abandoned, except those in Costa Rica (May and Plaza Lasso, 1958). Changes in amount of land under oil palm per country are shown in Figure 2.

In the $1950 \mathrm{~s}-1970$ s, oil palm was promoted by governments as a strategy to reach oil sufficiency, and to boost agricultural production and rural development. Public policies favored the sector, lands were distributed, and national plans were set up to promote and support palm oil production. In the 1980s-1990s, private groups were responsible for major development. We provide four examples of the role of public policies and of private companies in the development of the sector. Tables 1 and 2 are a detailed but non exhaustive list of public policies applied in the Americas to promote expansion of the palm oil sector.

In Mexico, the Chiapas government encouraged oil palm cultivation in the 1950s, but farmers were reluctant to convert pastures into plantations. Expansion did not occur until the 1990 s, in response to a sharp increase in domestic demand for fats and oils (Mata-Garcia, 2014). Some factors such as higher yields, the creation of producer organizations, and the political hegemony influenced the conversion of land to oil palm (Castellanos-Navarrete, 2018).

In Brazil, it was only in 1942 that the Ministry of Agriculture established the first formal plantation, in the state of Pará. In the 1950s, the agronomic institute, Instituto Agronômico do Norte (IAN), began distributing seeds and plants across the country. This initiative was reinforced in 1964 by the creation of a mill associated with 1000 ha of plantations and with 2000 ha of smallholdings. Public funds declined in the 1980s and were replaced by private investments. Many companies and factories were built and started to associate in specialized conglomerates (Homma Oyama, 2016).

In Colombia, in the late 1950s and early 1960s, the government promoted the plantation of 500 ha of oil palms, distributed in various regions. In 1962, producers started getting organized and created the National Federation of Oil Palm Growers (Fedepalma) (Fedepalma, 2002). In 1967, Fedepalma was put in charge of managing a thirty-year program for the development of the sector. The program included financial, commercial, and economic public incentives to promote rubber, cocoa, and oilseeds (Diario Oficial, 1957). Together with the Agrarian Financial Fund, it was one of the main drivers of the growth of oil palm production in Colombia and led to the funding of more than 20000 ha in the 1970s and another 66000 ha in the 1980s (EmpresayEconomía.com, 2012). 
Table 1. Examples of public policies applied in the Americas to support oil palm development; (a) Countries where public policies changed from incentive to regulative.

Tableau 1. Exemples de politiques publiques appliquées en Amérique pour accompagner le développement du secteur élaéicole; (a) Pays où les politiques publiques ont évolué de politiques incitatives à régulatrices.

\begin{tabular}{|c|c|c|c|c|c|c|}
\hline Country & $\begin{array}{l}\text { Title of the } \\
\text { public policy }\end{array}$ & Year(s) & $\begin{array}{l}\text { Content of } \\
\text { the public } \\
\text { policy }\end{array}$ & $\begin{array}{l}\text { Objectives of } \\
\text { the policy }\end{array}$ & Incentive & Regulative \\
\hline \multirow[t]{5}{*}{ Brazil } & $\begin{array}{l}\text { Planejamento } \\
\text { para a } \\
\text { Implantação da } \\
\text { Cultura do } \\
\text { Dendezeiro no } \\
\text { Pará }\end{array}$ & 1964 & $\begin{array}{l}\text { - establish } \\
\text { first } \\
\text { plantations }\end{array}$ & & $x$ & \\
\hline & $\begin{array}{l}\text { Programa } \\
\text { Nacional de } \\
\text { Pesquisa do } \\
\text { Dendê }\end{array}$ & $\begin{array}{l}1980- \\
1985\end{array}$ & $\begin{array}{l}\text { - provide } \\
\text { high quality } \\
\text { seedlings }\end{array}$ & $\begin{array}{l}\text { limit } \\
\text { dependence on } \\
\text { commercial } \\
\text { seeds and } \\
\text { seedlings }\end{array}$ & $x$ & \\
\hline & $\begin{array}{l}\text { Programa } \\
\text { Nacional De } \\
\text { Fortalecimento } \\
\text { Da Agricultura } \\
\text { Familiar } \\
\text { (PRONAF) } \\
\text { Eco/Dende }\end{array}$ & 1990s & $\begin{array}{l}\text { - offer a } \\
\text { preferential } \\
\text { interest rate } \\
\text { to oil palm } \\
\text { growers } \\
\text { - finance } \\
\text { scientific } \\
\text { improvement } \\
\text { - provide } \\
\text { technical } \\
\text { support. }\end{array}$ & & $x$ & \\
\hline & $\begin{array}{l}\text { Social Fuel Seal } \\
\text { (part of the } \\
\text { National } \\
\text { Program for } \\
\text { Production and } \\
\text { Use of Biodiesel } \\
\text { - PNPB) }\end{array}$ & 2005 & $\begin{array}{l}\text { - offer tax } \\
\text { breaks to the } \\
\text { industrial } \\
\text { mills } \\
\text { supplied by } \\
\text { smallholders }\end{array}$ & $\begin{array}{l}\text { promote social } \\
\text { inclusion, } \\
\text { stimulate } \\
\text { agricultural } \\
\text { production and } \\
\text { development in } \\
\text { marginal and } \\
\text { poor areas }\end{array}$ & & $x$ \\
\hline & $\begin{array}{l}\text { Programa de } \\
\text { Produção } \\
\text { Sustentável de } \\
\text { Palma de Óleo } \\
\text { no Brasil } \\
\text { (SPOPP) }\end{array}$ & 2010 & $\begin{array}{l}\text { - set new } \\
\text { regulations } \\
\text { and penalties } \\
\text { on } \\
\text { cultivation } \\
\text { areas } \\
\text { - establish } \\
\text { lines of credit } \\
\text { - provide } \\
\text { technical } \\
\text { assistance to } \\
\text { producers } \\
\text { - provide } \\
\text { research and } \\
\text { innovation } \\
\text { funds }\end{array}$ & $\begin{array}{l}\text { supervise the } \\
\text { development of } \\
\text { oil palm } \\
\text { cultivation, } \\
\text { restrict } \\
\text { plantations } \\
\text { development to } \\
\text { degraded areas, } \\
\text { preserve forests, } \\
\text { include family } \\
\text { farming }\end{array}$ & & $x$ \\
\hline \multirow[t]{2}{*}{ Colombia } & $\begin{array}{l}\text { Fondo de } \\
\text { Fomento } \\
\text { Palmero (FFP) }\end{array}$ & 1994 & $\begin{array}{l}\text { - fund } \\
\text { research and } \\
\text { marketing } \\
\text { programs }\end{array}$ & & $x$ & \\
\hline & $\begin{array}{l}\text { Decreto } 2354 \text { : } \\
\text { Fondo de } \\
\text { Estabilización } \\
\text { de Precios para } \\
\text { el Palmiste, el } \\
\text { Aceite de Palma } \\
\text { y sus Fracciones } \\
\text { (FEP palmero) }\end{array}$ & 1996 & & $\begin{array}{l}\text { stabilize the } \\
\text { income of } \\
\text { producers }\end{array}$ & $x$ & \\
\hline
\end{tabular}




\begin{tabular}{|c|c|c|c|c|c|c|}
\hline & $\begin{array}{l}\text { CONPES 3477: } \\
\text { Estrategia Para } \\
\text { El Desarrollo } \\
\text { Competitivo Del } \\
\text { Sector Palmero } \\
\text { Colombiano }\end{array}$ & 2007 & $\begin{array}{l}\text { - offer } \\
\text { credits to } \\
\text { renew crops } \\
\text { and to } \\
\text { modernize } \\
\text { extraction } \\
\text { mills } \\
\text { - support the } \\
\text { first } \\
\text { productive } \\
\text { alliance with } \\
640 \text { families }\end{array}$ & $\begin{array}{l}\text { sustainably } \\
\text { increase the } \\
\text { competitiveness } \\
\text { and production } \\
\text { of the sector }\end{array}$ & $x$ & \\
\hline & $\begin{array}{l}\text { CONPES } 3510 \text { : } \\
\text { Lineamientos } \\
\text { de política para } \\
\text { promover la } \\
\text { producción } \\
\text { sostenible de } \\
\text { biocombustibles } \\
\text { en Colombia }\end{array}$ & 2008 & & $\begin{array}{l}\text { produce } \\
\text { knowledge on } \\
\text { environmental } \\
\text { issues, } \\
\text { encourage an } \\
\text { environmental } \\
\text { certification } \\
\text { program for } \\
\text { biofuels, zoning } \\
\text { of biofuel } \\
\text { establishment } \\
\text { areas, promote } \\
\text { reduction of } \\
\text { GHG emissions, } \\
\text { strengthen } \\
\text { environmental } \\
\text { regulations }\end{array}$ & & $x$ \\
\hline \multirow[t]{3}{*}{ Ecuador } & $\begin{array}{l}\text { Plan de Mejor } \\
\text { Competitiva de } \\
\text { la cadena palma } \\
\text { de aceite (PMC) }\end{array}$ & 2014 & & $\begin{array}{l}\text { analyze the } \\
\text { sector and its } \\
\text { prospects, } \\
\text { design strategic } \\
\text { development }\end{array}$ & & \\
\hline & Decreto 427 & 2014 & $\begin{array}{l}\text { - offer tax } \\
\text { exemptions } \\
\text { for growers } \\
\text { in the region } \\
\text { of the } \\
\text { Esmeraldas }\end{array}$ & & $x$ & \\
\hline & PROPALMA & 2015 & $\begin{array}{l}\text { - provide } \\
\text { training and } \\
\text { certification } \\
\text { to growers }\end{array}$ & $\begin{array}{l}\text { increase the } \\
\text { productivity of } \\
\text { the sector }\end{array}$ & & $x$ \\
\hline \multirow[t]{3}{*}{ Peru } & $\begin{array}{l}\text { Decreto } \\
\text { Supremo 015- } \\
\text { 2000-AG }\end{array}$ & 2000 & $\begin{array}{l}\text { - declare the } \\
\text { oil palm } \\
\text { plantations } \\
\text { of national } \\
\text { interest }\end{array}$ & $\begin{array}{l}\text { recover land } \\
\text { allocated to } \\
\text { migratory } \\
\text { agriculture and } \\
\text { illegal crops } \\
\text { (coca) by } \\
\text { establishing oil } \\
\text { palm plantations }\end{array}$ & $x$ & \\
\hline & $\begin{array}{l}\text { Plan Nacional } \\
\text { de Promocion } \\
\text { de la Palma } \\
\text { Aceitera. Perú } \\
\text { 2000-2010 }\end{array}$ & 2001 & & $\begin{array}{l}\text { expand oil palm } \\
\text { in the } \\
\text { Amazonian } \\
\text { region }\end{array}$ & $x$ & \\
\hline & $\begin{array}{l}\text { Plan Nacional } \\
\text { de Desarrollo } \\
\text { Sostenible de la } \\
\text { Palma Aceitera } \\
\text { en el Peru } \\
\text { (Resolucion } \\
\text { Ministerial } \\
\text { N.o0565-2015- } \\
\text { Minagri) }\end{array}$ & 2015 & & $\begin{array}{l}\text { strengthen and } \\
\text { sustainably } \\
\text { improve the } \\
\text { competitiveness, } \\
\text { improve the } \\
\text { services offered } \\
\text { to producers, } \\
\text { improve } \\
\text { institutions and } \\
\text { policies related } \\
\text { to oil palm } \\
\text { cultivation }\end{array}$ & & $x$ \\
\hline
\end{tabular}


Table 2. Examples of public policies applied in the Americas to support oil palm development; (b) Countries where public policies remain mostly incentive.

Tableau 2. Exemples de politiques publiques appliquées en Amérique pour accompagner le développement du secteur élaéicole; (b) Pays où les politiques publiques restent majoritairement incitatrices.

\begin{tabular}{|c|c|c|c|c|c|c|}
\hline Country & $\begin{array}{l}\text { Title of the } \\
\text { public policy }\end{array}$ & Year(s) & $\begin{array}{l}\text { Content of the } \\
\text { public policy }\end{array}$ & $\begin{array}{l}\text { Objectives } \\
\text { of the policy }\end{array}$ & Incentive & Regulative \\
\hline \multirow[t]{3}{*}{ Costa Rica } & $\begin{array}{l}\text { Plan nacional } \\
\text { de oleaginosas }\end{array}$ & $\begin{array}{l}1984- \\
1989\end{array}$ & $\begin{array}{l}\text { - offer loans } \\
\text { to oil palm } \\
\text { growers }\end{array}$ & & $x$ & \\
\hline & $\begin{array}{l}\text { Ley de la } \\
\text { Republica } \\
\text { N7062 }\end{array}$ & 1986 & $\begin{array}{l}\text { - grant credits } \\
\text { to producers } \\
\text { - provide } \\
\text { advice and } \\
\text { training } \\
\text { - construction } \\
\text { of an agro- } \\
\text { industrial } \\
\text { cooperative }\end{array}$ & & $x$ & \\
\hline & $\begin{array}{l}\text { Proyecto } \\
\text { Agroindustrial } \\
\text { de Palma } \\
\text { Aceitera }\end{array}$ & 1990 & $\begin{array}{l}\text { - favor the } \\
\text { construction } \\
\text { of two } \\
\text { processing } \\
\text { plants for } \\
\text { cooperative } \\
\text { producers }\end{array}$ & $\begin{array}{l}\text { limit the } \\
\text { monopolistic } \\
\text { structure of } \\
\text { the sector }\end{array}$ & $x$ & \\
\hline \multirow[t]{3}{*}{ Guatemala } & $\begin{array}{l}\text { Decreto 29-89 } \\
\text { (artículo 12) of } \\
\text { the « Ley de } \\
\text { Fomento y } \\
\text { Desarrollo de } \\
\text { la Actividad } \\
\text { Exportadora y } \\
\text { de Maquila » }\end{array}$ & 1989 & $\begin{array}{l}\text { - provide } \\
\text { large oil palm } \\
\text { companies } \\
\text { with tax } \\
\text { exemption for } \\
10 \text { years }\end{array}$ & & $x$ & \\
\hline & $\begin{array}{l}\text { Decreto 52- } \\
2003 \text {, of the } \\
\text { « Ley de } \\
\text { Incentivos } \\
\text { para el } \\
\text { Desarrollo de } \\
\text { Proyectos de } \\
\text { Energía } \\
\text { Renovable " }\end{array}$ & 2003 & $\begin{array}{l}\text { - provide tax } \\
\text { exemption to } \\
\text { companies } \\
\text { producing } \\
\text { energy from } \\
\text { palm oil } \\
\text { - provide VAT } \\
\text { refunds to } \\
\text { exporters }\end{array}$ & & $x$ & \\
\hline & PROPALMA & 2008 & $\begin{array}{l}\text { - provide } \\
\text { financial } \\
\text { assistance to } \\
\text { small } \\
\text { producers } \\
\text { (<25 hectares) }\end{array}$ & $\begin{array}{l}\text { boost oil } \\
\text { palm } \\
\text { cultivation }\end{array}$ & $x$ & \\
\hline \multirow[t]{2}{*}{ Honduras } & $\begin{array}{l}\text { Mesa Agricola } \\
\text { Palma Africana } \\
\text { (part of the } \\
\text { Mesa Agricola } \\
\text { Hondureña) }\end{array}$ & 2002 & & $\begin{array}{l}\text { guide and } \\
\text { rule oil palm } \\
\text { industry }\end{array}$ & $x$ & \\
\hline & $\begin{array}{l}\text { Acuerdo } \\
\text { Marco para la } \\
\text { competitividad } \\
\text { de la palma } \\
\text { africana y } \\
\text { otras } \\
\text { palmáceas }\end{array}$ & 2006 & $\begin{array}{l}\text { - offer a } \\
\text { financial } \\
\text { system } \\
\text { adapted to } \\
\text { late-yielding } \\
\text { crops } \\
\text { - provide } \\
\text { technical } \\
\text { assistance } \\
\text { - assist the } \\
\text { transport of } \\
\text { FFB }\end{array}$ & & $x$ & \\
\hline
\end{tabular}


Table 2. Continued

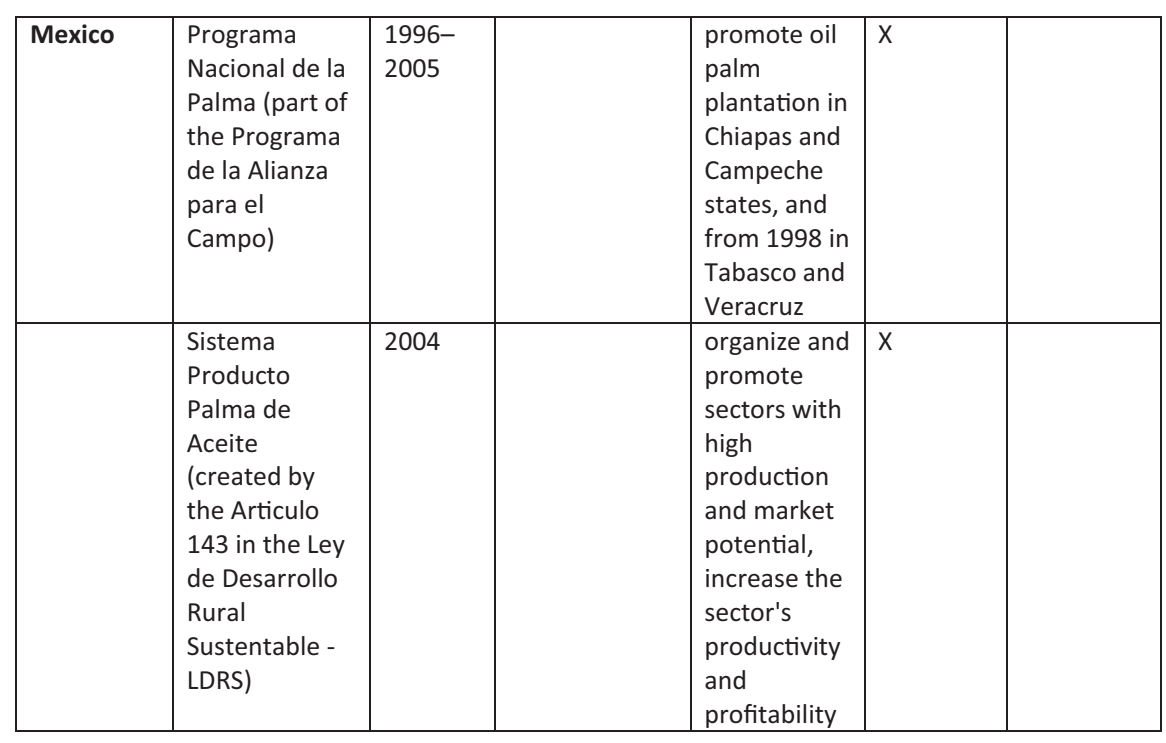

350000

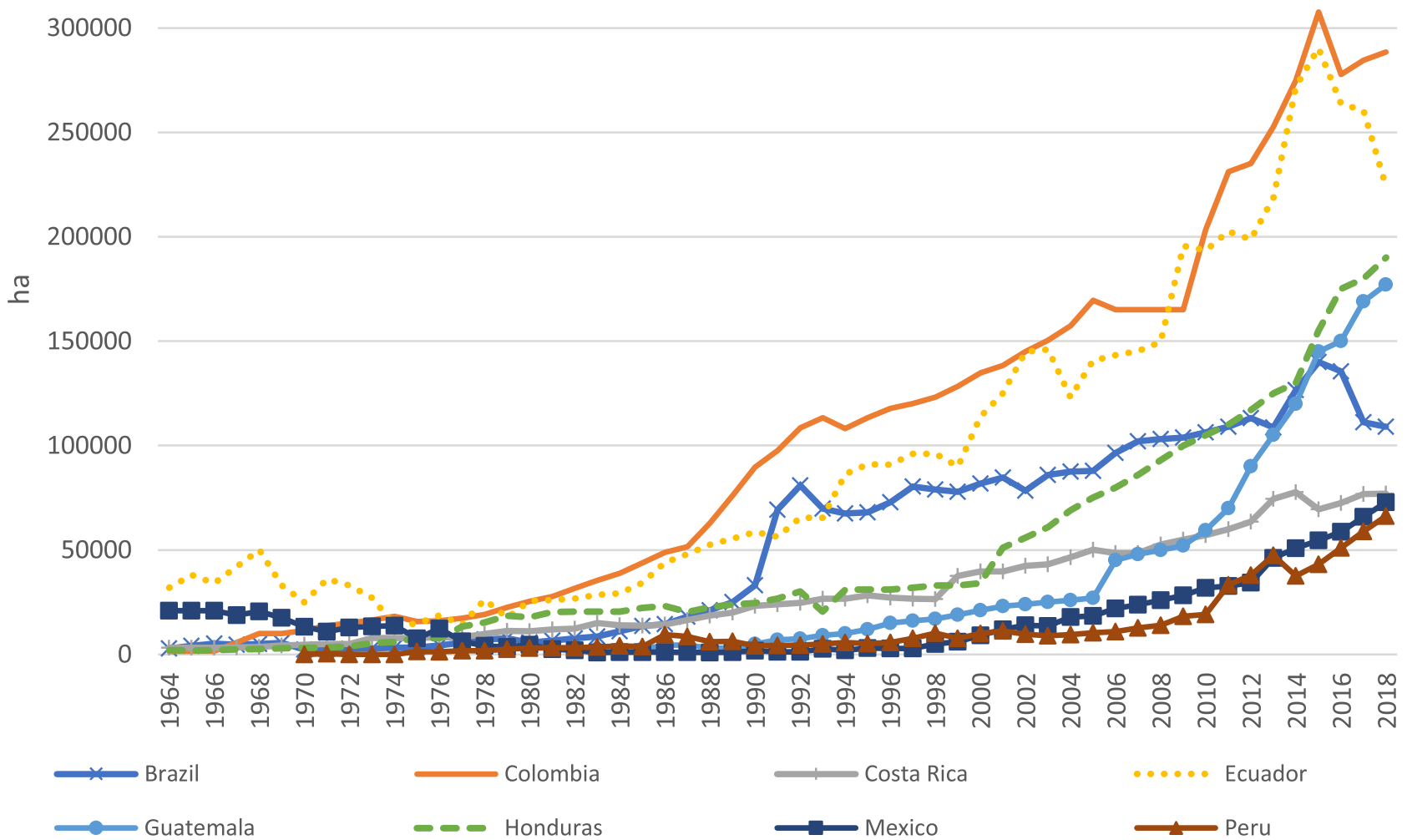

Fig. 2. Changes in land under oil palm per country in the eight main producing countries. Source: FAO (2020).

Fig. 2. Évolution de la superficie cultivée par pays dans les huit principaux pays producteurs. 
In Honduras, the government distributed 40700 ha to 3000 family farmers which included 6600 ha of oil palm and assistance to growers (BID et al., 1971). At the end of the 1990s, Honduras also underwent a massive expansion of largescale private agro-industrial plantations.

\subsection{Three palm oil production models}

Palm oil can be produced in very different situations, especially concerning the cultivation techniques used in the plantations, the type of oil extraction mill, the type of actors involved, and the relations between the actors. We grouped the cases in the literature into three categories of palm oil production systems based on the arrangements between fresh fruit bunch (FFB) growers and palm oil extraction units: 1) corporate models, 2) contract faming, and 3) growers' organizations.

The corporate model is the most common model in the Americas, accounting for almost $70 \%$ of the regional production. In this corporate model, the company owns one or more production units, each composed of a mill surrounded by a plantation, possibly large enough to meet the mill extraction capacity. The proximity of the plantation facilitates transport of the FFBs and limits costs. The past development of this model was mainly the result of private investments that were supported by governments through public policies (Gutiérrez-Vélez et al., 2011). To complete the supply of FFBs, some sales agreements might be signed with growers' organizations.

The contract farming model is well illustrated by the strategic alliances, which started in the 1980s in Colombia. Growers own the plantation land and are organized in a private business association. They sign an exclusive sales agreement with the company that owns a mill and which provides seeds and assistance, and social programs. Contract farming is popular in Brasil, Colombia, Costa Rica, Guatemala, Honduras, México, and Perú. In some cases, the growers' organization shares a binding commitment to the association's contract with the mill (De la Rosa, 2012).

The third category, growers' organizations, is defined as FFB growers organized in a cooperative or association which (partially or fully) owns an extraction mill. As shareholders, growers receive profits from the sales of the final products in addition to what they earn from the sale of their FFB. This category is well illustrated by the Mexican "social sector" which is not specific to oil palm. Initiated in the 1980s in Mexico, it is defined by the National Constitution of Mexico (Poder Legislativo, 1996) as social ownership based on cooperation and associative administration similar to the ejidos and the agrarian communities (Bouquet and Colin, 2009). At the end of the 1990s, the federal government of Mexico launched the "National palm oil program". Most of the plantations established in this program were organized based on this model. According to Sagarpa (2004) $96 \%$ of the growers and $70 \%$ of Mexican palm oil production in 2004 were based on this model. Similar models exist in Costa Rica, Honduras, Nicaragua, Panama, and Peru, where they were promoted by the governments. This type of growers' share in a mill appears to be specific to the Americas but shares features with initiatives led by NGOs in Africa and Asia to develop smallholder palm oil production independently of large groups (Proforest, 2016; Smit et al., 2015; Solidaridad, 2014).
In all three models, independent growers can sell their FFB directly to mills as an additional supply.

Most papers analyzed the sector's structure in terms of the number of growers involved, or the percentage of production or the area allocated to one of the models. The information available in the literature in 2017 on this subject is summarized in Figure 3 but is incomplete, which is why some countries are not represented and for some others, the total does not add up to $100 \%$ total. Nevertheless, the figure provides useful insights into the contrasted distribution of production models among the countries, which partly results from public policies promoting palm oil production.

As summarized in Tables 1 and 2, two main types of public policies have been applied to promote the development of oil palm: in-kind provision of subsidies (seeds, fertilizers, training, etc.) or fiscal benefits (tax reduction). One of the requirements to access these incentives may be formalized land tenure. In Colombia, this was accompanied by facilitated access to corporate enterprises in partnership with growers, while in Mexico, this was targeted by communal tenure (ejidos). In both cases, production of FFB by small and medium growers was promoted.

\section{What are the challenges to sustainability?}

\subsection{Impacts reported in the literature}

With the rapid expansion of oil palm plantations, controversies arose and economic, social, and environmental impacts were reported in the literature. In this section, we summarize the main points but the list is not exhaustive. Few references provide a comparative analysis of the impacts of each model.

Regarding deforestation in the Americas, it was calculated that most of the oil palm plantations were established at the expense of land uses that were not well-preserved natural ecosystems, but rather degraded herbaceous vegetation $(56 \%)$, and agricultural lands (23\%), while in Ecuador, Peru, Brazil, and Guatemala, $21 \%$ of the expansion mainly occurred at the expense of forested areas (Furumo and Aide, 2017). In Guatemala and Brazil, more than $70 \%$ of production is by large producers ( $>200 \mathrm{ha}$ ), but in Peru and Ecuador, 56\% of production is by small and medium producers (CastellanosNavarrete et al., 2020); there is thus no direct clear link between deforestation and the type of oil palm production model. Yet, the corporate model is the main target of criticism and the large-scale expansion of plantations is identified by non-scientific media as being responsible for deforestation, land grabbing, and water pollution. However, at global scale, tropical deforestation is still dominated by small scale farming (Austin et al., 2017) and there is no evidence that the same does not apply to oil palm. The relationship is complex and has to be analyzed at country scale to account for historical and context specificities, which is true for all agricultural production (see Feintrenie et al., 2019).

The conversion of grasslands or food crops into oil palm might enable some recovery of biodiversity (Butler and Laurance, 2009; Droulers et al., 2010) like in Mexico, where small-scale plantations (less than $100 \mathrm{ha}$ ) serve as corridors between forest patches for some species of mammals (Knowlton et al., 2019). However the same plantations limit 


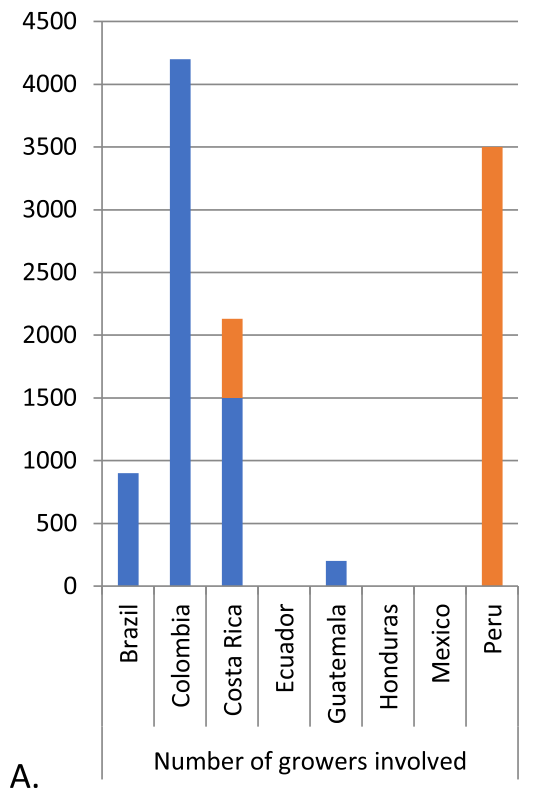

A.

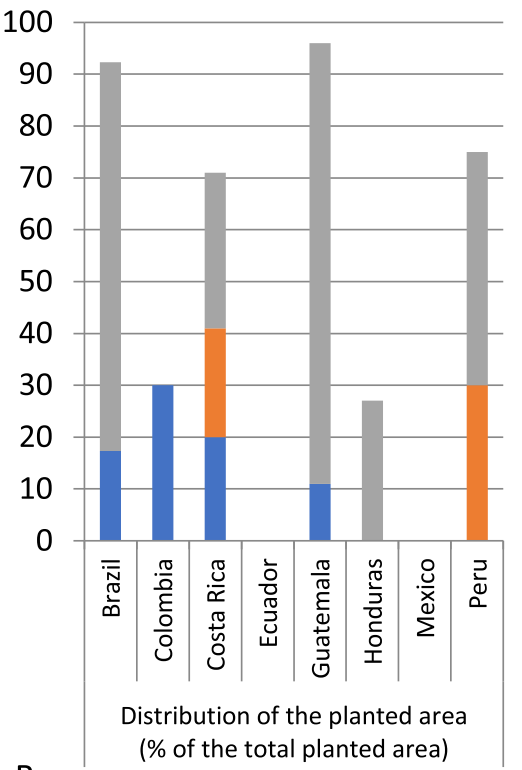

B.

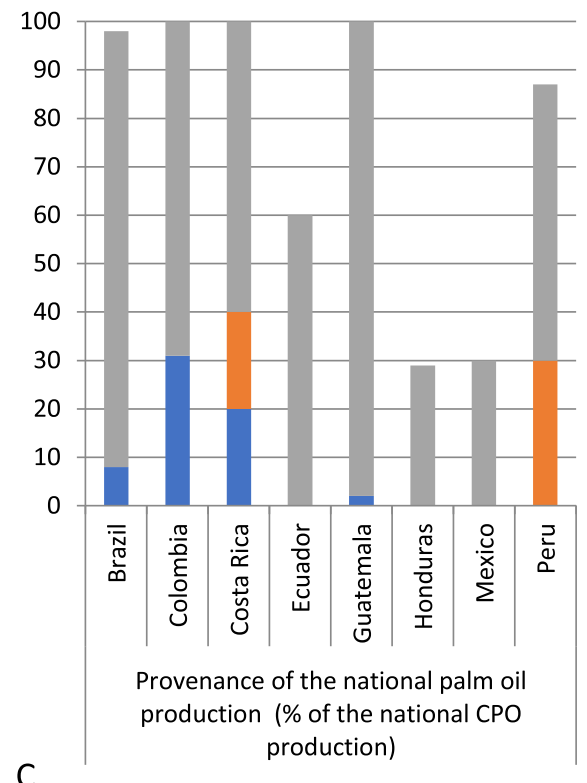

- Strategic alliances $\quad$ Social sector Private companies

Fig. 3. Importance of the three production models in terms of (A) numbers of growers involved, (B) planted area, and (C) production. Fig. 3. Importance des trois modèles économiques selon (A) le nombre de producteurs impliqués, (B) la superficie plantée, et (C) la production.

the movement of birds between forest fragments (Knowlton et al., 2021), showing that the impact of oil palm plantations on biodiversity has to be analyzed at the landscape scale, not only considering their role in structural connectivity but also in functional connectivity for groups of species of interest. Pollution of water and soil, and the excessive use of fertilizers or pesticides, have direct negative impacts on insects, soil fauna and aquatic species. Well managed fertilization and pest and disease control depend on knowledge of the needs of the plantation at a specific time, and hence on the ability to evaluate them, and on seedlings resistance capacities.Repercussions of the expansion of oil palm production for food security and access to water for rural populations also raise concerns. Quiroga and Vallejo (2019) described competition for water between plantations and rural communities caused by some infrastructure policies that were originally designed to favor rural development. Concerns about the conversion of food crops into oil palm plantations and the direct repercussions on food security have been raised in Mexico (Hernandez-Rojas et al., 2018), Brazil, Colombia (Potter, 2015) and Guatemala (Guereña and Zepeda, 2013). However, in Mexico, Rosas Urióstegui et al. (2018) concluded that oil palm cultivation does not necessarily compete with the food security of those who grow oil palm as a livelihood, since it contributes to the family economy and to job diversification. Conversely, in Colombia, despite the higher incomes reported between 1993 and 2009 in oil palm municipalities, oil palm expansion resulted in land concentration and an increase of unmet basic needs in rural populations (Castiblanco et al., 2014), whereas in Tabasco, Mexico, Pischke et al. (2018) showed that palm oil production and its future expansion were relatively well perceived by the communities since economic, societal, and environmental benefits were associated with it.

Country case studies underline that the socio-economic impacts of oil palm development is more influenced by public policies than by the nature of the arrangements between agricultural producers and primary processing units (Bennet et al., 2018; Castellanos-Navarrete et al., 2020). However, a comparative analysis of the three models based on actual benefits perceived by growers, number of jobs generated, longterm income security and risks for growers in the different models (resistance to economic, ecologic or agronomic crisis) remains to be performed at the regional scale.

The purchase of land by oil palm growers may be accompanied by violence and threats to reluctant local land users. Among the most frequently cited issues are theft and looting of palm plantations, the repression and persecution of local communities, and the presence of paramilitaries. These are most common in Honduras (Cour Pénale Internationale, 2015), Guatemala (Guereña and Zepeda, 2013) and Colombia (Mingorance, 2006; Ballvé, 2009). Examples of indigenous land distributed to migrant settlers without the consent of indigenous people can be observed in Honduras (Salva la Selva, 2014), Ecuador (Ramos, 2008), and Peru (Forest Peoples Programme, 2016). In addition to direct land grabbing, speculation or the inflation of land prices may occur on the periphery of the plantations and make it easier for migrants than for local ethnic groups to acquire formal land rights (Dammert et al., 2012; Bennett et al., 2018).

\subsection{A political move towards more sustainability}

In response to these criticisms, most of the countries and actors have changed their production policies. Programs and actions have been launched to limit the negative impacts of oil palm expansion and encourage more sustainable development (Tab. 1). In this way, governments have shifted from "incentive policies", favoring expansion of the sector, to "regulatory policies", to ensure the sector develops sustainably. 
For example, in 2005, Brazil launched the sustainable oil palm production program which aims are to reduce the country's dependence on imported fossil fuel, preserve the environment, and promote family and cooperative agriculture and social inclusion (Ministry of Mines and Energy, 2005). This program has helped reduce the rate of deforestation in the state of Pará (Benami et al., 2018). It set up new regulations and penalties: planting oil palm is only authorized on land deforested and used before 2007 or located in an agroecological zone with established geographical limits for oil palm plantations (Homma Oyama, 2016). The National Development Bank of Brazil is authorized to issue advantageous loans for plantations in degraded areas and to refuse loans for nondegraded areas (Englund et al., 2015).

In Colombia, the Rural Capitalization Incentive was created to support producers in areas threatened by oil palm diseases. It provides subsidies for seeds for small producers, and for large producers who partner them. This incentive has resulted in rapid multiplication of strategic alliances (Fedepalma, 2010). However, Borón et al. (2016) showed that even if the national policy agenda benefited oil palm growers and had a positive economic impact, it will continue to have negative impacts on biodiversity unless conservation policies are designed and implemented with the participation of the different national and territorial institutions. Such a participatory approach, with the validation of the stakeholders, would reflect the reality of the sector and would have a real impact at the local level.

In Ecuador, in 2012, the Agreement No 015 of the Ministry of the Environment stated that, depending on their production area, producers must apply for an environmental license ( $>100 \mathrm{ha}$ ), submit a declaration ( 50 to $100 \mathrm{ha})$ or a record ( $<75 \mathrm{ha})$ that are supposed to guarantee the sustainability of plantations. Agroecological zoning also defines where production should be located to respect the RSPO criteria, which the government will help implement (Agrocalidad, 2015).

In parallel to changes in public policies toward incentives that favor sustainable production, other actors have become involved in certification. As an illustration, in the Americas, RSPO reached 355300 ha of certified plantations and 1057871 MT of Certified Sustainable Palm Oil (CSPO) in 2019 (RSPO, 2020).

\section{Conclusions}

We classified palm oil production systems in the Americas according to the arrangements between FFB growers and oil extraction units in: 1) corporate models, 2) contract farming, and 3 ) growers' organizations. The rise of contract farming and the increased participation of growers' organization in the financial capital of extraction units have been supported by public policies aiming at an inclusive development of the production sector. However, the type of arrangement among production actors is not a guarantee of positive impacts on the environment nor on the local populations. Thus public policies shifted from providing incentives to providing regulatory frameworks, and private groups accompanied this movement by engaging in certification (such as RSPO) and NDPE commitments.
No direct and simple relation can be made between the category of palm oil production system and the social, economic and environmental impacts of oil palm development. Impacts are influenced by contextual factors and actors' engagement regarding their societal and environmental responsibility. Case studies confirm the importance of the socio-political context in the socio-economic impacts of oil palm development. The way land tenure and allocation are included in agricultural development policies and programs, has a direct impact on the category of people who will benefit from them. However, a corporate model applied in the absence of arrangements with independent growers (whether they are organized or not) is the least likely to have extensive positive socio-economic impacts.

Biodiversity is affected by cultivation practices and effluent management. If companies have the financial means to use high quality planting material and have easier access to technical knowledge, independent growers could also have access to the same material and knowledge through contract farming or growers' organization, or through incentive programs. The three production models may or may not apply biodiversity-friendly practices in their plantations and mills. This will be determined by their knowledge of such practices, their desire to implement them, their access to inputs, to technical training and to capacity building, and will be directly influenced by the public regulations and controls applied.

Regarding biodiversity, the structure of plantations and how they are organized in a landscape might be more important than the size of the plots. Landscape ecologists have demonstrated the importance of both structural and functional connectivity in maintaining the circulation of biodiversity. The preservation or restoration of connectivity should be combined with protection of natural habitats. Public conservation and national and territorial land use planning policies may have a bigger impact on biodiversity and high conservation value habitats than the type of palm oil production model.

The growing demand for vegetable oil will remain the main driver of palm oil sector development. The pressure of the global society for a sustainable and inclusive development influences public policies and international corporates, and drive them to take commitments. However, the step between commitments and actual changes in the financial and technical aspects is difficult to climb. Context specific researches are needed to argue on the costs and benefits of the various production models, and to inform the conditions for a sustainable oil palm development in the Americas. Facilitation of an informed dialogue among the numerous stakeholders at local and national scales is also key to ensure the integration of oil palm development in the territories.

\section{Funding}

The research received financial support from PalmElit SAS (Montpellier, France). The funder had no role in the organization of the study, in data collection and interpretation, or in the presentation and publication of the results.

Acknowledgements. We thank the anonymous reviewers for their valuable and constructive comments, and Daphne Goodfellow for reviewing the English. 


\section{References}

Agrocalidad. 2015. Guia de buenas practicas agricolas para el cultivo de palma aceitera. http://www.agrocalidad.gob.ec.

Austin KG, González-Roglich M, Schaffer-Smith D, Schwantes AM, Swenson J. 2017. Erratum: Trends in size of tropical deforestation events signal increasing dominance of industrial-scale drivers (2017 Environmental Research Letters 5: 054009). Environmental Research Letters 12: 079601.

Ballvé T. 2009. The dark side of plan Colombia. The Nation 15: 22 32.

Benami E, Curran L, Cochrane M, Venturieri A, Franco R, Kneipp J, et al. 2018. Oil palm land conversion in Pará, Brazil, from 20062014: Evaluating the 2010 Brazilian Sustainable Palm Oil Production Program. Environmental Research Letters 13: 1-12. https://doi.org/10.1088/1748-9326/aaa270.

Bennett A, Ravikumar A, Cronkleton P. 2018. The effects of rural development policy on land rights distribution and land use scenarios: The case of oil palm in the Peruvian Amazon. Land Use Policy 70: 84-93. https://doi.org/10.1016/j.landusepol.2017.10.011.

BID, IICA, Consuplan. 1971. Fomento del Cultivo de la Palma Africana en el Valle del Aguan.

Borón V, Payán E, MacMillan D, Tzanopoulos J. 2016. Achieving sustainable development in rural areas in Colombia: Future scenarios for biodiversity conservation under land use change. Land Use Policy 59: 27-37. https://doi.org/10.1016/j.landuse pol.2016.08.017.

Bouquet E, Colin JP. 2009. L'État, l'ejido et les droits fonciers: ruptures et continuités du cadre institutionnel formel au Mexique. Paris (France) : Éditions Karthala, pp. 299-332.

Butler RA, Laurance WF. 2009. Is oil palm the next emerging threat to the Amazon? Tropical Conservation Science 2(1): 1-10. https:// doi.org/10.1177/194008290900200102.

Byerlee D, Falcon WP, Naylor R. 2017. The tropical oil crop revolution: food, feed, fuel, and forests. Oxford (UK): Oxford University Press. https://doi.org/10.1093/acprof:oso/ 9780190222987.001.0001.

CAB Direct. 2017. Database. https://www.cabdirect.org/cabdirect.

Carrión L, Cuvi M. 1985. La palma africana en el Ecuador: Tecnología y expansión empresarial. Quito (Ecuador): Facultad Latinoamericana de Ciencias Sociales (FLACSO), $26 \mathrm{p}$.

Castellanos-Navarrete A. 2018. Palma de aceite en tierras campesinas: la política de las transformaciones territoriales en Chiapas, México. Revista pueblos y fronteras digital 13.

Castellanos-Navarrete A, de Castro F, Pacheco P. 2020. The impact of oil palm on rural livelihoods and tropical forest landscapes in Latin America. Journal of Rural Studies 81: 294-304. https://doi.org/ 10.1016/j.jrurstud.2020.10.047.

Castiblanco C, Etter A, Ramirez A. 2014. Impacts of oil palm expansion in Colombia: What do socioeconomicindicators show? Land Use Policy 44: 31-43. https://doi.org/10.1016/j.landuse pol.2014.10.007.

Clare P. 2005. El desarrollo del banano y la palma aceitera en el Pacífico costarricense desde la perspectiva de la Ecología Histórica. Diálogos Revista Electrónica 6(1): 308-346. https:// doi.org/10.15517/dre.v6i1.6211.

Cour Pénale Internationale. 2015. Situation au Honduras-Rapport établi au titre de l'article 5 du Statut. https://www.icc-cpi.int/Pages/ item.aspx ?name $=$ otp-stat-28-10-2015\&ln=fr.

Dammert JL, Cárdenas K, Canziani E. 2012. Potenciales impactos ambientales y sociales del establecimiento de cultivos de palma aceitera en el departamento de Loreto (No. E90 D34).
De la Rosa. 2012. De las alianzas estrategicas a los negocios inclusivos. Revista Palmas 33(2): 96-68.

Diario Oficial. 1957. Decreto 290 de 1957. Sistema Unico de Información Normativa.

Droulers M, Venturieri A, Mourão M, Thalês M, Poccard R. 2010. Le palmier à huile: un avenir pour l'Amazonie? Revue francobrésilienne de géographie (10): 1-20. https://doi.org/10.4000/ confins.6867.

EmpresayEconomía.com. 2012. Fedepalma, 50 años contribuyendo al desarrollo de Colombia. http://www.marcasymercados.com/.

Englund O, Berndes G, Persson UM, Sparovek G. 2015. Oil palm for biodiesel in Brazil-Risks and opportunities. Environmental Research Letters 10(4): 044002. https://doi.org/10.1088/ $1748-9326 / 10 / 4 / 044002$.

FAO. 2020. FAOSTAT database. http://www.fao.org/faostat/en/\#data/ QC.

Fedepalma. 2002. La palma de aceite: un producto con historia. Boletín El Palmicultor 368: 19-20.

Fedepalma. 2010. Las alianzas productivas estratégicas en palma de aceite Un modelo vigente, con resultados importantes, pero que requiere ajustes para asegurar su sostenibilidad. MIDAS, USAID Programa. https://repositorio.fedepalma.org/.

Feintrenie L, Betbeder J, Piketty MG, Gazull L. 2019. Deforestation for food production. In: Dury S, Bendjebbar P, Hainzelin E, Giordano T, Bricas N, eds. Food Systems at risk: new trends and challenges. Rome, Montpellier, Brussels: FAO, CIRAD and European Commission, pp.43-46. https://doi.org/10.19182/agri trop/00089.

Forest Peoples Programme. 2016. Compañía del grupo Melka se retira de la RSPO. http://www.forestpeoples.org/es/topics/agro negocios/news/2016/11/.

Furumo PR, Aide TM. 2017. Characterizing commercial oil palm expansion in Latin America: land use change and trade. Environmental Research Letters 12(2): 024008. https://doi.org/ 10.1088/1748-9326/aa5892.

Guereña A, Zepeda R. 2013. The power of oil palm: Land grabbing and impacts associated with the expansion of oil palm crops in Guatemala: The case of the Palmas del Ixcán Company. Oxfam America Research Backgrounder Series, $64 \mathrm{p}$.

Gutiérrez-Vélez V, DeFries R, Pinedo-Vásquez M, Uriarte M, Padoch C, Baethgen W, et al. 2011. High-yield oil palm expansion spares land at the expense of forests in the Peruvian Amazon. Environmental Research Letters 6(4): 044029. https://doi.org/ 10.1088/1748-9326/6/4/044029.

Hernandez-Rojas DA, Lopez-Barrera F, Bonilla-Moheno M. 2018. Preliminary analysis of the land use dynamic associated with oil palm (Elaeis guineensis) plantations in Mexico. Agrociencia (Montecillo) 52(6): 875-893.

Homma Oyama AK. 2016. Cronologia do cultivo do dendezeiro na Amazônia. Belém (Brésil): Embrapa, 52 p.

IICA. 2006. Cultivo de la Palma Africana: Guia técnica. Instituto Interamericano de Cooperación para la Agricultura. https:// vdocuments.mx/cultivo-de-la-palma-africana-guia-tecnica.html.

Knowlton JL, Mata-Zayas EE, Ripley A, Valenzuela-Cordova B, Collado-Torres R. 2019. Mammal diversity in oil palm plantations and forest fragments in a highly modified landscape in southern Mexico. Frontiers in Forests and Global Change 2: 67. https://doi. org/10.3389/ffgc.2019.00067.

Knowlton JL, Halvorsen KE, Flaspohler DJ, Webster CR, Abrams J, Almeida SM, et al. 2021. Birds and bioenergy within the americas: A cross-national, social-ecological study of ecosystem service tradeoffs. Land 10: 1-21. https://doi.org/10.3390/land10030258. 
Les Echos. 2009. United Fruit, la mère des républiques bananières. https://www.lesechos.fr/2009/07/united-fruit-la-mere-des-republi ques-bananieres-474488.

Mata-Garcia B. 2014. Palma de aceite en México. Política gubernamental e innovación tecnológica. Mexico (Mexique): Centro de Estudios para el Desarrollo Rural Sustentable y la Soberanía, $114 \mathrm{p}$.

May S, Plaza Lasso G. 1958. United fruit company in Latin America. Meijaard E, Sheil D. 2019. The moral minefield of ethical oil palm and sustainable development. Frontiers in Forests and Global Change 2: 22. https://doi.org/10.3389/ffgc.2019.00022.

Meijaard E, Garcia-Ulloa J, Sheil D, Wich S, Carlson K, Juffe-Bignoli $\mathrm{D}$, et al. 2018. Oil palm and biodiversity: A situation analysis by the IUCN Oil Palm Task Force. https://doi.org/10.2305/IUCN. CH.2018.11.en.

Mingorance F. 2006. The flow of palm oil Colombia-Belgium/ Europe: A study from a human rights perspective. Bruxelles (Belgique), $84 \mathrm{p}$.

Ministry of Mines and Energy. 2005. National Biodiesel Production and Use Program (Brésil).

Pacheco P, Hospes O, Dermawan A. 2017. Zero deforestation and low emissions development: Public and private institutional arrangements under jurisdictional approaches. Bogor (Indonesia): CIFOR, WUR, $8 \mathrm{p}$.

Pirker J, Mosnier A, Kraxner F, Havlík P, Obersteiner M. 2016. What are the limits to oil palm expansion? Global Environmental Change 40: 73-81. https://doi.org/10.1016/j.gloenvcha.2016.06.007.

Pischke EC, Rouleau MD, Halvorsen KE. 2018. Public perceptions towards oil palm cultivation in Tabasco, Mexico. Biomass and Bioenergy (112): 1-10. https://doi.org/10.1016/j.bio mbioe.2018.02.010.

Poder Legislativo. 1996. Constitución política de los estados unidos mexicanos. Mexico (Mexique): Editorial Porrua SA, Ultima Edición, $418 \mathrm{p}$.

Potter L. 2015. Managing oil palm landscapes: A seven-country survey of the modern palm oil industry in Southeast Asia, Latin America and West Africa. Bogor (Indonesia): CIFOR, 154 p.

Proforest. 2016. Proforest's Programmes. https://www.proforest.net/ en/files/proforest_programme_brochure_aug16_web.pdf.

Qaim M, Sibhatu KT, Siregar H, Grass I. 2020. Environmental, economic, and social consequences of the oil palm boom. Annual
Review of Resource Economics 12. https://doi.org/10.1146/ annurev-resource-110119-024922.

Quiroga C, Vallejo D. 2019. Territorios de agua: infraestructura agrícola, reforma agraria y palma de aceite en el municipio de Marialabaja (Bolívar). Revista Colombiana de Antropología 55: 59-89. https://doi.org/10.22380/2539472X.570.

Ramos I. 2008. Ecuador: impactos sociales y ambientales de la palma aceitera. https://wrm.org.uy/es/articulos-del-boletin-wrm/seccion3/ ecuador-impactos-sociales-y-ambientales-de-la-palma-aceitera/.

Rosas Urióstegui FI, Pat Fernández JM, Pat Fernández LA, van der Wal JC. 2018. The effect of oil palm on income strategies and food security of households in rural communities in Campeche, Mexico. Acta Universitaria 28(2): 25-35. https://doi.org/10.15174/ au.2018.1553.

RSPO. 2020. Impact Report 2019. https://www.rspo.org/resources/ archive/1324.

Sagarpa. 2004. Plan Nacional del Sistema Producto Palma de aceite 2004-2014. Mexico (Mexique), 78 p.

Salva la Selva. 2014. Palma Aceitera Desangra a Honduras. https:// www.salvalaselva.org/peticion/887/pama-aceitera-desangra-a-hon duras? pr3vU_ =\#more.

Santika T, Wilson KA, Meijaard E, Budiharta S, Law EE, Sabri M, et al. 2019. Changing landscapes, livelihoods and village welfare in the context of oil palm development. Land Use Policy 87: 104073. https://doi.org/10.1016/j.landusepol.2019.104073.

Smit H, McNally R, Gijsenbergh A. 2015. Implementing deforestation-free supply chains-certification and beyond. https://snv.org/ cms/sites/default/files/explore/download/implementing_deforesta tion-free_supply_chains.pdf.

Solidaridad. 2014. Towards inclusive palm oil supply chains. https:// www.solidaridadnetwork.org/sites/solidaridadnetwork.org/files/ publications/Solidaridad_palmoil_leaflet_2014.pdf.

USDA. 2017. Production supply and distribution online. https://apps. fas.usda.gov/psdonline/app/index.html\#/app/home.

Washburn R. 1987. Historia del cultivo de la palma aceitera en Centroamérica III. El único de la explotación palmera en la división de Coto. 4. IICA, pp. 102-103.

Watkins C. 2018. Landscapes and resistance in the African diaspora: Five centuries of palm oil on Bahia's Dendê Coast. Journal of Rural Studies 61: 137-154. https://doi.org/10.1016/j.jrurstud.2018.04.009.

Cite this article as: Lesage C, Cifuentes-Espinosa J, Feintrenie L. 2021. Oil palm cultivation in the Americas: review of the social, economic and environmental conditions of its expansion. Cah. Agric. 30: 27. 